\title{
HADIS PADA MASA NABI MUHAMMAD SAW DAN SAHABAT
}

\author{
Radinal Mukhtar Harahap \\ Sekolah Tinggi Ilmu Tarbiyah (STIT) Ar-Raudlatul Hasanah \\ Jl. Setia Budi, Simpang Selayang, Medan Tuntungan, 20135, Sumatera Utara, Indonesia \\ Email: radinalmukhtarhrp@gmail.com
}

\begin{abstract}
Discourses on hadith in the Prophet's time and His companions are important in initiating study ulum al-hadith. This is because one of the function of hadith as the explanatory verses of the Koran. This article will try to elaborate some approaches of library research in ulum al-hadith (1) How the companions received, memorized applied those hadith in their life. (2) Commands and prohibitions were not generalized to all companions in writing hadith. (3) The maintenance of hadits at the companions era from lost and also from mingled with Qur'an. (4) Distributed those hadith to the vast area of Islam at the time (5) All narrators of hadith to be agreed by scholars as good people and behavior. (6) there were some criteria of fairness for companions ('adālah al-șahābah), namely, Muslims, maturity, intelligent, piety, selfrespect, avoiding him self from cases of fasiq, to be acknowledge their fairness, and free from criticism of scholars.
\end{abstract}

Keywords: The Prophet's Time, The Companions's Time, 'Adālah al-Sahābah

\begin{abstract}
Abstrak
Pembahasan hadis pada masa Nabi dan Sahabat adalah penting dalam memulai kajian ulūm alHadīs. Hal ini karena hadis merupakan penjelas ayat Alquran yang diturunkan global dan diseru Allah-meski tersirat, untuk mengetahuinya. Dengan pendekatan literatur (library research) tulisan ini mengelaborasi (1) cara sahabat menerima hadis, yaitu menghafal, menulis dan memraktekkannya, (2) perintah dan larangan penulisannya yang tidak bersifat 'àm atau menyeluruh kepada seluruh sahabat, (3) pemeliharaan hadis masa sahabat, dari hilangnya maupun bercampur dengan nas Alquran atau kepalsuan yang dibuat-buat (4) penyebarannya, yang tidak terlepas dari luasnya wilayah Islam pada masa itu (5) sahabat-sahabat periwayat hadis, yang meskipun jumlahnya tidak terperinci tetapi disepakati semuanya adil dan (6) keadilan sahabat ('adālah al-șahābah) dengan 9 indikator, yaitu muslim, balig, āqil, takwa, murū'ah, terhindar dari sebab-sebab fāsiq, terhindar dari cela-cela murū'ah, diakui ke-'adālah-annya dan bebas dari kritik al-'Ārifin.
\end{abstract}

Kata Kunci: Hadis, Masa Nabi, Masa Sahabat, adālah al-șahābah

\section{Pendahuluan}

Muștafā al-Sibā'i, dalam bagian awal disertasinya yang kemudian diterbitkan menjadi buku berjudul alSunnah wa Makānatuhā fì al-Tasyrī’ alIslāmī, menyebutkan bahwa ayat-ayat Alquran diturunkan kepada Nabi Muhammad saw. dalam bentuk global (mujmalah). Ia memberi contoh bahwa perintah salat, di dalam Alquran, tidak menyebutkan berapa jumlah rakaat, bagaimana bentuk pelaksanaannya, dan kapan-kapan saja waktunya. Begitu juga dengan perintah zakat yang tidak disertai penjelasan mengenai batas-batas minimal (al-had al-adnā) suatu harta yang wajib dikeluarkan zakatnya. Hal ini berdampak keharusan para sahabat untuk merujuk langsung kepada Rasulullah saw agar mengerti perihal hukum-hukum yang 
terkait dengan ayat-ayat global dimaksud.

Begitu juga dengan peristiwa-peristiwa yang tidak ditetapkan oleh ayat-ayat Alquran, maka penjelasan mengenainya adalah dari keterangan dan penjelasan Rasulullah saw. karena beliau adalah orang yang paling tahu (adrā al-khalq) atas maksud-maksud yang terkandung dalam syariat, baik batas-batasnya, bentuk pelaksanaannya, maupun tujuan terpenting darinya. ${ }^{1}$

Selain itu, Alquran sendiri sejatinya telah memerintahkan untuk mentaati dan mengikuti Rasul, ${ }^{2}$ karena Ia merupakan sosok yang mempunyai akhlak yang terpuji, ${ }^{3}$ dan semestinya menjadi panutan dan teladan bagi ummatnya. ${ }^{4}$ Bahkan untuk mempelajari segala sesuatu yang datang dari Rasul-selain Alquran-berupa perkataan, perbuatan, penetapan (taqrīr), sifat-sifat (khalqiyah am khuluqiyah) dan sejarah perjalanan hidup beliau (qabla 'ām ba 'da bi ‘́sah seperti tahannus di gua hirā'), yang itu merupakan definisi Hadis, ${ }^{5}$ dan

\footnotetext{
${ }^{1}$ Muștafā al-Sibā'‘̄, al-Sunnah wa Makānatuhā fì al-Tasrī‘ al-Islāmī, cet. II (Beirut: Al-Maktab al-Islāmī, 1396 H/ 1976 M), 49.

${ }^{2}$ Lihat misalnya Q.S. Al-Hasyr/5: 7, Āli 'Imrān/3: 31, 32, al-Nisā'/4: 80.

${ }^{3}$ Q.S. al-Qalām/68: 4.

${ }^{4}$ Q.S. al-Ahzāb/33: 21.

${ }^{5}$ Ini adalah definisi hadis menurut para muhaddisìn. Berbeda dengan ulama ușūl yang mendefinisikan hadis sebagai segala sesuatu yang berasal dari Rasulullah, selain Alquran, baik perkatan, perbuatan atau taqrīr, yang dapat digunakan sebagai dalil dalam penetapan hukum syariat. Baca selengkapnya di Mụ̣ammad 'Ajjāj al-
}

juga ilmu-ilmu lainnya, adalah termasuk perintah dari Allah, ${ }^{6}$ yang menjadi pembeda antara orang yang berilmu dan yang tidak berilmu, ${ }^{7}$ serta mendapat ganjaran berupa lebih tinggi beberapa derajat ketimbang yang tidak mengetahui. ${ }^{8}$

Hal ini penting untuk dikemukakan terlebih dahulu sebab, meskipun telah terlarang dengan beredar dan terbitnya Keputusan Mahkamah Agung RI No: KEP169/J.A/9/1983 dan Nomor: KEP059/J.A/3/1984, kelompok Ingkar Sunnah lebih-lebih di Indonesia, tetap eksis dan ada. Abdul Majid Khon, dari UIN Syarif Hidayatullah, menyatakan itu dalam penelitiannya yang dimuat di jurnal Teologia, Vol. 23, No. 1, Januari 2012 dengan menyebutkan bahwa eksistensi paham ingkar sunnah berkembang secara sembunyi di berbagai media, baik buku, koran, buletin dan lain sebagainya. ${ }^{9}$

Dengan latar belakang tersebut di atas, tulisan ini hadir untuk menjelaskan secara umum perihal hadis yang menitikberatkan pembahasan kepada keberadaan hadis pada masa Nabi

Khațīb, Ușūl al-Hadīis 'Ulūmuh wa Muṣtalaḥuh, cet. II (Beirut: Dār al-Fikr, 1391 H/1971 M), 19.

${ }^{6}$ Q.S. al-'Alaq/96: 1.

${ }^{7}$ Q.S. al-Zumar/39: 9.

${ }^{8}$ Q.S. al-Mujādalah/58: 11.

${ }^{9}$ Abdul Majid Khon, "Paham Ingkar Sunah di Indonesia: Studi Tentang Pemikirannya." Jurnal Teologia, vol. 23, no. 1 (Januari 2012): 58. Baca juga Relit Nur Edi, "Al-Sunnah (Hadis); Suatu Kajian Aliran Ingkar Sunnah," Jurnal Asas, vol. 6, no. 2 (Juli 2014): 132-148. 
Muhammad saw dan para Sahabat. Kajian yang akan dielaborasi adalah (1) cara sahabat menerima hadis masa Nabi saw, (2) perintah dan larangan penulisan hadis masa Nabi saw, (3) pemeliharaan hadis masa sahabat, (4) penyebaran hadis di masa sahabat, (5) beberapa uraian mengenai sahabat-sahabat yang menjadi periwayat hadis, dan (6) perihal keadilan sahabat ('adālah al-ṣaḥābah). Dengan penjelasan itu, tulisan ini diharapkan dapat menjadi pintu masuk dalam mengkaji perihal ilmuilmu hadis lainnya, baik pembagianpembagiannya, yang dilihat dari kuantitas periwayat atau kualitasnya dan penisbatan hadis tersebut, -qudsī, marfī', mauqūf, maqtū', kajian terhadap sanad dan matan, takhrīj hadis, jarh dan ta'dīl, ataupun penelusuran terhadap kitab-kitab mu'tabar.

\section{Cara Sahabat Menerima Hadis Masa} Nabi saw.

Muhammad Muhammad Abū Zahw, dalam Al-Hadīis wa al-Muhaddis̄ūn al'Ināyah al-Ummah al-Islāmiyah bi alSunnah al-Muhammadiyyah, menyebutkan bahwa sebenarnya sahabat Rasul adalah orang Arab tulen ('arab khāliṣ) yang mayoritas tidak bisa baca-tulis. Akan tetapi, mereka itu adalah orang-orang yang mempunyai kemampuan menghafal luar biasa, yang dapat dilihat dari kemampuan mereka menghafal nasab/garis keturunan sampai nenek moyangnya, riwayat-riwayat tentang kejadian yang dialami, dan bahkan mereka pun hafal syair-syair dan khițābahkhițābah yang pernah diucapkan. ${ }^{10}$ Dengan demikian, ditegaskannya kemudian, seakanakan (ka anna) Allah telah mempersiapkan kemampuan orang-orang arab itu untuk mendukung datangnya kenabian Muhammad saw. ${ }^{11}$ Bahkan, dengan kekuatan itu pula, hingga saat ini, umat Islam menjadi umat yang senantiasa menjaga kemurniaan kitab Allah dan hadis Rasulnya. $^{12}$

Sahabat Rasul yang dimaksud di atas bukan hanya laki-laki. Hal ini sebagaimana dijelaskan oleh Muhammad 'Ajjāj al-Khațīb yang menyebutkan bahwa perempuan juga belajar kepada Rasulullah (ta'lìm al-nisā'). Dikatakan bahwa Rasulullah selalu datang mengajar mereka setelah sebelumnya berjanji akan memberikan pengajaran pada tempat dan waktu yang telah ditentukan. ${ }^{13}$ Dengan demikian, definisi sahabat sebagaimana yang dikemukakan oleh Ibnu Hajar al'Asqalān̄̄ sebagai orang yang berjumpa

\footnotetext{
${ }^{10}$ Muhammad Muhammad Abū Zahw, AlHadīs wa al-Muhaddis̄ūn al-'Ināyah al-Ummah alIslāmiyah bi al-Sunnah al-Muhammadiyyah (Riyad: al-Ri'āsah al-'Āmmah li Idārah al-Buhūù al-'Ilmiyah wa al-Iftā’ wa al-Da'wah, 1404 H/ 1984 M), 49.

${ }^{11} \mathrm{Abū}$ Zahw, al-Hadīs, 49-50.

${ }^{12} \mathrm{Abū}$ Zahw, al-Hadīis, 50.

${ }^{13}$ Al-Khațīb, Ușūl, 65.
} 
dengan Nabi saw, ${ }^{14}$ dalam keadaan beriman dan wafat dalam keadaan Islam, ${ }^{15}$ tidak dikhususkan hanya kepada laki-laki saja, melainkan juga perempuan.

M. M. Azami, lewat karya monumentalnya yang berjudul Studies in Hadìth Methodology and Literature, menyebutkan tiga cara yang dilakukan Nabi dalam menyampaikan hadis, yang sekaligus menjelaskan tiga cara sahabat Nabi menerima hadis, yaitu: (1) menyampaikan hadis dengan kata-kata. Nabi banyak mengadakan pengajaran-pengajaran melalui ucapan - kepada para sahabat, dan bahkan untuk memudahkan dalam memahami dan mengingat hadis yang disampaikan, Rasul sering mengulangulang perkataannya sampai tiga kali. Dari sini terlihat bahwa sahabat menerima hadis dengan hafalan. (2) Menyampaikan hadis melalui media tertulis atau Rasul mendiktekan kepada sahabat yang pandai menulis. Ini menyangkut seluruh surat Rasul yang ditujukan kepada para raja,

\footnotetext{
${ }^{14}$ Termasuk dalam arti berjumpa di sini adalah sahabat-sahabat yang ikut majelis Rasulullah dalam waktu yang lama atau hanya sebentar saja, sahabat-sahabat yang meriwayatkan hadis atau tidak, sahabat-sahabat yang ikut berperang bersama Rasulullah atau tidak. Juga, maksud berjumpa di sini adalah, yang melihat Nabi meskipun tidak dalam satu majelis, bahkan yang tidak melihat sekalipun karena buta. Aḥmad bin 'Alī bin al-'Asqalān̄̄, alIșābah, juz I (Beirut: Dār al-Kutub al-'Ilmiyah, 1415 H/ $1995 \mathrm{M}), 158$.

${ }^{15}$ Al-'Asqalānī, al-Ișābah, juz I, 158. Lihat juga Muḥammad Șiddīq al-Mansyāwi, Qāmūs Muștalaḥāt al-Hadīis al-Nabawī (Kairo: Dār alFaḍilah, t.th.), 72.
}

penguasa, kepala suku dan gubernurgubernur muslim. Beberapa di antara surat tersebut berisi tentang ketetapan-ketetapan hukum Islam seperti ketentuan tentang zakat, tata cara peribadatan dan sebagainya. Dari sini terlihat bahwa sahabat menerima hadis dengan tulisan. (3) Menyampaikan hadis dengan praktek secara langsung. Rasul banyak melakukan perbuatanperbuatan yang dipraktikkan secara langsung untuk memberikan contoh kepada para sahabat, seperti beliau mengajarkan cara wuduk, salat, puasa, menunaikan ibadah haji dan sebagainya. Dari sini terlihat bahwa sahabat menerima hadis dengan praktek secara langsung atas apa yang disampaikan Rasul. ${ }^{16}$

Muḥammad Ajjāj al-Khațīb menjelaskan lebih rinci, sebagaimana berikut:

1. Dari majelis-majelis Rasulullah. Seluruh majelis Rasul adalah majelis ilmu. Beliau selalu menentukan terlebih dahulu waktu untuk mengajar para sahabatnya dan hal ini ditanggapi antusias tinggi oleh para sahabat, namun sebagian mereka ada yang tidak bisa menghadiri majelis

\footnotetext{
${ }^{16}$ Muhammad Mustafa Azami, Studies In Hadith Methodology And Literature (Indiana: American Trust Publications, 1977), 9-10, 13-14.
} 
karena kesibukannya sehingga bergantian, ${ }^{17}$ dengan tetangganya. ${ }^{18}$

2. Kejadian-kejadian yang dialami Rasul sendiri, kemudian beliau menjelaskan hukumnya sehingga hukum yang ditetapkan oleh Rasul (hadis taqrīr) dan diketahui para sahabat dan kemudian menyebar keseluruh orang muslim. ${ }^{19}$

3. Kejadian-kejadian yang dialami para sahabat, kemudian ditanyakan hukumnya kepada Rasul, sehingga Rasul memberi penjelasan tentangnya. Hal ini sangat sering terjadi. $^{20}$

4. Perbuatan-perbuatan yang dilakukan Rasul dan disaksikan para sahabat, seperti tata cara salat, puasa, ibadah haji, ketika beliau dalam perjalanan dan sebagainya. ${ }^{21}$

Muhammad Muhammad Abū Zahw menjelaskan perihal ini dengan pendekatan lain, yaitu: (1) Berhadapan secara langsung dengan Rasul (Musyāfahah),

Menyaksikan (Musyāhadah) perbuatan atau

\footnotetext{
${ }^{17}$ Muhammad Muhammad Abū Zahw menukil dari Sahịh al-Bukhārī bahwa 'Umar bin Khațāab dan tetangganya dari golongan ansar bergantian untuk menghadiri majelis Rasulullah dan siapapun di antara mereka yang hadir memberitahu apa yang dilihat dan didengarnya dari Rasul. Baca Abū Zahw, al-Hadīis, 51.

${ }^{18}$ Al-Khațīb, Ușūl, 67.

${ }^{19} \mathrm{Al}-\mathrm{Khațīb}$, Ușūl, 68.

${ }^{20} \mathrm{Al}-\mathrm{Khațīb}, U s ̦ \bar{u} l, 68-70$.

${ }^{21} \mathrm{Al}-\mathrm{Khațīb}$, Ușūl, 70.
}

taqrir Rasul, (3) Mendengar dari sahabat lain yang mengetahui secara langsung. ${ }^{22}$

\section{Perintah dan Larangan Penulisan Hadis} Masa Nabi saw.

Telah dijelaskan sebelumnya bahwa sahabat Rasul mayoritasnya tidak bisa bacatulis. Pernyataan demikian sekaligus menggambarkan bahwa ada beberapa sahabat yang mahir dalam hal itu, meski bukan mayoritas. M. M. Azami dalam kitabnya yang berjudul Kuttāb al-Nabī Śallā Allāh 'alaihi wa Sallam, ada 48 sahabat yang menjadi sekretaris Nabi dan juru tulisnya. ${ }^{23}$

Pendapat yang populer adalah sahabat-sahabat tersebut penulis Alquran, dan bukan hadis. Pendapat itu kemudian dikaitkan dengan diriwayatkan oleh Abū Sa‘̄id al-Khudrī, bahwa Rasullah saw bersabda: "Janganlah kamu sekalian menulis - apa yang kamu dengar dariku selain dari Alquran, barangsiapa yang telah menulis selain dari Alquran, maka hapuskanlah". ${ }^{24}$ Padahal, dalam tuturan Mușțafā al-Sibā'‘̄, beberapa sahabat telah menuliskan apa yang mereka dengar dari

\footnotetext{
${ }^{22} \mathrm{Abū}$ Zahw, al-Hadīis, 53.

${ }^{23}$ Baca selengkapnya di Muhammad Mușțafā al-A'zamī, Kuttāb al-Nab̄̄ șallā Allāh 'alaihi wa Sallam, cet. II (Beirut: al-Maktab al-Islāmī, 1398 H/ $1978 \mathrm{M}$ )

${ }^{24}$ Hadis ini diriwayatkan oleh Muslim (bab Zuhd; 72), al-Dārimī (muqaddimah: 42) dan Aḥmad (3, 21, 39). A. J. Wensinck, al-Mu 'jam al-Mufahras Li Alfāz al-Hadìs al-Nabawī, jilid V (Leiden: E. J. Brill, 1936), 519.
} 
Rasulullah saw., seperti 'Abdullāh bin 'Amrū bin 'Aṣ yang mempunyai șahīfah bernama șädiqah. ${ }^{25}$ Mengomentari itu, lanjut Muștafā al-Sibā‘‘̄e Abū Hurayrah diriwayatkan berkata, "Tidak ada seorangpun yang lebih mengetahui hadis Rasulullah saw. dibanding aku, kecuali 'Abdullāh bin 'Amrū. Hal ini karena ia telah mencatatnya sedangkan aku tidak." ${ }^{26}$ Bahkan, saat fathu makkah, Rasul bersabda: “Tuliskanlah untuk Abū Syah ini!', 27 yaitu perihal penyelesaian suatu kasus.

Dua hadis di atas, perintah menulis dan larangannya, terlihat seakan kontradiktif. Hal ini yang kemudian dibantah oleh M. M. Azami lewat karyanya yang berjudul Dirāsāt fì al-Hadīis alNabawī wa Tārīkh Tadwīnih. Ia membahasnya dalam 13 halaman kitab tersebut dengan kesimpulan sebagai berikut: ${ }^{28}$

1. Larangan menulis hadis adalah larangan yang tersemat (mubayyinan) pada kondisi dan situasi khusus, seperti seseorang yang baru masuk Islam atau menuliskannya dalam satu alat dengan Alquran.

\footnotetext{
${ }^{25} \mathrm{Al}-\mathrm{Sibā} ‘ \overline{1}$, al-Sunnah, 49.

${ }^{26} \mathrm{Al}-\mathrm{Sib} \overline{\mathrm{a}}{ }^{\prime} \overline{1}$, al-Sunnah, 49.

${ }^{27}$ Hadis ini diriwayatkan oleh al-Bukhārī (bab 'ilm; 39 dan luqațah; 7), al-Dārimī (manāsik: 89 dan diyāt; 4), al-Tirmiżī (bab 'ilm; 4), dan Aḥmad (2, 238). Wensinck, al-Mu 'jam, jilid V, 524.

${ }^{28}$ Muhạmmad Mușțafā al-A'ẓamī, Dirāsāt fì al-Hadīs al-Nabaw̄ wa Tārīkh Tadwīnuh (Beirut: Maktab al-Islāmī, 1400 H/ 1980 M), 83.
}

2. Larangan menulis hadis adalah larangan menulisnya bersamaan dengan Alquran-dalam lembaran yang sama atau waktu yang sama-dan hal itu agar tidak tercampur antara redaksi firman Allah dengan tafsiran Nabi.

3. Larangan untuk menulis hadis tidak berlaku umum dan setiap saat (lam takun 'āmmah wa lā dā'imah). Hal itu dikarenakan fakta bahwa ada sejumlah sahabat yang menuliskan hadis di masa Nabi, dan Nabi mengizinkannya.

Ṣubḥ̄ al-Ṣāliḥ menyebut perihal hadis larangan menulis di atas adalah salah satu di antara penyebab sedikitnya penulisan hadis di zaman Rasulullah. ${ }^{29}$

\section{Pemeliharaan Hadis Masa Sahabat}

Tidak diragukan lagi bahwa kontribusi para sahabat Rasul dalam memelihara hadis sangatlah besar. Itu karena mereka yang langsung bertemu dengan Rasul, baik mendengar maupun menyaksikan hadis-hadis terucap maupun diamalkan. Mereka juga orang-orang yang mengklarifikasi hukum-hukum terkait hadis secara langsung, sehingga, dengan demikian, kontribusi yang mereka berikan adalah keniscayaan. Namun demikian,

\footnotetext{
${ }^{29}$ Șubḥī al-Ṣālị̣, 'Ulūm al-Hadìs $\quad$ wa Muṣtalāḥuh (Beirut: Dār al-'Ilmi li al-Malāyīn, 1977), 17-23.
} 
sebagaimana yang menjadi catatan dari Șubḥī al-Ṣāliḥ dalam 'Ulūm al-Hadīs wa Muștalahuh-nya, hadis-hadis yang dihafal jauh lebih banyak ketimbang dari hadis yang tertulis. ${ }^{30}$ Alasannya dapat dijelaskan dengan pembahasan sebelumnya, bahwa (1) para sahabat adalah bangsa Arab yang mempunyai kekuatan dalam menghafal, dan (2) mereka adalah bangsa yang mayoritas tidak pandai menulis. ${ }^{31}$

Selanjutnya, dalam upaya memelihara Hadis juga, para sahabat dikenal sangat teliti. Abū Bakr, misalnya, dalam Muwațta' Mālik bin Anas diceritakan menghadapi kasus waris untuk seorang nenek, yang meminta hak waris dari harta yang ditinggalkan oleh cucunya. Abū Bakr menjawab, bahwa tidak ada bagian baginya dari petunjuk Alquran maupun praktek Nabi. Abū Bakr lalu bertanya kepada para sahabat. Maka al-Mugīrah ibn Syu'bah menyatakan kepadanya, bahwa Nabi telah memberikan bagian waris kepada nenek sebesar seperenam bagian. Mendengar pernyataan tersebut, Abū Bakr meminta agar al-Mugīrah menghadirkan seorang saksi. Lalu Muhammad ibn Maslamah memberikan kesaksian atas kebenaran pernyataan al-Mugīrah. Akhirnya Abū Bakr

\footnotetext{
${ }^{30}$ Al-Șāliḥ, 'Ulūm, 24-30.

${ }^{31} \mathrm{Abū}$ Zahw, al-Hadìs, 49.
}

memberikan seperenam bagian. ${ }^{32}$

Sahabat 'Umar bin Khațāā, dalam penuturan Imam Abū 'Abdullāh Syams alDīn al-Żahabī di Tażkirah al-Huffāz, dinyatakan pernah menyuruh para sahabat untuk tidak banyak (an yaqilla) meriwayatkan hadis-hadis Nabi. Hal itu dikarenakan ia khawatir bahwa para sahabat menyibukkan diri dengan hadis-hadis dan kemudian melupakan hifž Alquran. ${ }^{33}$ Perintah tidak banyak meriwayatkan hadis tersebut tentu bukan sebuah larangan, karena, 'Umar bin Khaț̣āb sendiri, dalam catatan Aḥmad ibn 'Alī ibn Ḥajar al'Asqalān̄̄, mempunyai banyak hadis yang diriwayatkan oleh banyak sahabat. ${ }^{34}$

Demikianlah sikap para sahabat dalam memelihara hadis. Baik memeliharanya dari hilangnya, atau bercampurnya dengan nas Alquran. Yang pertama mereka mengandalkan kemampuan hafalan yang kuat. Yang kedua dengan kehati-hatiannya yang cermat. Faktor kedua ini pula yang disinyalir memperlambat penyebaran hadis di masa sahabat.

\footnotetext{
${ }^{32}$ Mālik Ibn Anas, al-Muwatța', bab alFarāị (Mesir: Dār al-Sya ‘b, t.t.), 397.

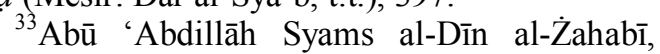
Tażkirah al-Huffāż, juz I (Beirut: Dār al-Kutub al'Ilmiyah, t.th.), 6-7.

${ }^{34}$ Aḥmad Ibn 'Alī Ibn Hajar al-'Asqalānī, Tahżīb al-Tahżīb, juz. VII (India: Majlis Dā'irah alMa‘ārif al-Niz̄āmiyah, 1325 H), 439.
} 


\section{Penyebaran Hadis di Masa Sahabat}

Sikap hati-hati yang dilakukan oleh

Abū Bakr dan 'Umar bin Khațāāb, sebagaimana telah dijelaskan sebelumnya, sejatinya tampak juga dalam diri 'Us̉mān bin 'Affān, ${ }^{35}$ dan 'Alī bin Abī Ṭālib.

Namun demikian, seruan-seruan mereka terlihat tidak begitu besar pengaruhnya terhadap para periwayat tertentu yang bersikap "longgar" (al-mukassirirūn) dalam periwayatan hadis. Bisa jadi, dalam kasus pribadi 'Uṡmān bin 'Affān, karena ia tidak sekeras 'Umar bin Khațāā. Adapun dalam kasus 'Alī bin Abī Ṭālib, ia sedang berhadapan dengan pertentangan politik di kalangan umat Islam yang makin menajam. Selain itu, wilayah Islam saat mereka berdua menjadi khalifah telah makin luas. Luasnya wilayah Islam mengakibatkan bertambahnya kesulitan pengendalian kegiatan periwayatan hadis secara ketat. ${ }^{36}$

Di satu sisi, luasnya daerah wilayah Islam mengakibatkan hal tersebut di atas. Namun, di sisi lain, luasnya daerah mengakibatkan para sahabat dapat

${ }^{35}$ Dalam suatu kesempatan khutbah, 'Uṡmān Bin 'Affān meminta agar para sahabat tidak banyak meriwayatkan hadis yang mereka tidak pernah mendengar hadis itu pada masa Abū Bakr dan 'Umar. Baca Muhammad 'Ajjāj al-Khațīb, alSunnah qabl al-Tadwinn (Kairo: Maktabah Wahbah, 1963), 97-98.

${ }^{36}$ Dalam Tażkirah al-Huffāz dinyatakan bahwa 'Alī bin Abī Țālib baru bersedia menerima riwayat hadis setelah periwayat hadis yang bersangkutan mengucapkan sumpah, bahwa hadis yang disampaikannya itu benar-benar berasal dari Nabi. Baca al-Żahabī, Tażkirah, juz I, 10-11. menyebarkan hadis kepada sahabat lain dan tābi 'īn. ${ }^{37}$ Tābi 'ìn yang menerima riwayat hadis lalu menyampaikan hadis itu kepada tābi'ìn atau kepada atbā' al-tābi'ìn (generasi umat Islam sesudah tābi 'inn), demikian seterusnya. Sehingga hadis itu akhirnya sampai kepada periwayat yang melakukan kegiatan penghimpunan hadis. Buah karya para penghimpun hadis (almukharrij) itulah yang menjadi sumber pengetahuan dan rujukan hadis pada masa berikutnya sampai pada masa sekarang.

Terkait penyebaran Hadis juga, M.

M. Azami membaginya kepada empat periode, yaitu: ${ }^{38}$

1. Periode penulisan pada generasi sahabat, di abad pertama hijriyah

2. Periode penulisan pada generasi senior (kibār) tābi'īn, di abad pertama hingga 105 hijriyah

3. Periode penulisan dan kodifikasi karya, di permulaan abad kedua.

4. Periode penulisan generasi junior (ṣigār) tābi 'īn dan atbā' al-tābi 'īn, di $3 / 4$ akhir abad kedua.

${ }^{37} T a \bar{a} b i$ 'ìn adalah bentuk plural dari tāa bi 'T yang didefinisikan sebagai mereka yang menemani (sahaba) para Sahabat. Tidak cukup hanya bertemu sebagai bentuk kemuliaan atas Rasulullah saw, dikarenakan perjumpaan dengan Rasulullah telah berdampak pada hati, sedangkan pada sahabat tidak. Namun demikian, mereka yang hanya bertemu dengan para sahabat dalam keadaan percaya (mu'minan) pada risalah nabi, inilah pendapat yang kuat. Lihat al-Mansyāwī, Qāmūs Mușțalaḥāt alHadīs al-Nabawī, 72.

${ }^{38}$ Al-A'ẓamī, Dirāsāt, 85. 


\section{Jumlah Sahabat Periwayat Hadis}

Tidak ada informasi yang terperinci mengenai jumlah para sahabat. ${ }^{39}$ Namun, ulama sepakat (ittafaqa) bahwa semua sahabat adalah adil ('udūl), kecuali pendapat-pendapat aneh dari golongan yang menyimpang, ${ }^{40} \quad$ (illā syużūi $\dot{z}$ min mubtadi'ah). ${ }^{41}$ Sahabat yang pertama adalah yang masyhur dengan nama Abū Bakr al-Șiddīq. ${ }^{42}$ Sedangkan yang terakhir meninggal dunia adalah Abū al-Ṭufayl 'Āmir bin Wāṡilah al-Layṡ̄̄ yang meninggal di Mekkah $110 \mathrm{H}^{43}$

Selanjutnya, sahabat-sahabat Rasul tersebut dibagi menjadi 12 țabaqāt (tingkatan) yang hal ini akan berdampak pada pembagian hadis kepada mutawātir atau $\bar{a} h \bar{a} d$-nya. Ibnu Hazm menukilnya dari Hākim sebagai berikut: ${ }^{44}$

${ }^{39} A b u \overline{~ M u h a m m a d ~ ' A l i ̄ ~ b i n ~ A h ̣ m a d ~ b i n ~}$ 'Abdillāh bin Sa'īd bin Hazm al-Zahirah alAndalusī, Asmā' al-Ṣahābah wa Mā likulli Wāhidin Minhum min al-'Adad (Riyād: Maktabah al-Sa'i, t.th.), 11 .

${ }^{40}$ Dalam menjelaskan makna golongan yang menyimpang (mubtadi'ah), Ibrāhīm bin 'Āmir alRāhilī menyebutkan bahwa mereka adalah Khawārij, Rāfidah, Murjiah, Qadariyah, Jahmiyah Mu'attilah, Musyabbihah Mumasssilah. Baca Ibrāhīm bin 'Āmir al-Rāhilī, Mauqifu Ahl al-Sunnah wa alJamā'ah min Ahl al-Ahwā'i wa al-Bida', juz I (Madinah: Maktabah al-Gharba' al-Aṡariyah, 1415 H), 11.

${ }^{41} \mathrm{Al}$-'Asqalānī, al-Ișābah, juz I, 162.

${ }^{42}$ Nama aslinya adalah 'Abdullāh bin Abī Qahāfah 'Us̀mān al-Qurasȳì al-Taimī. Lihat Abū 'Abdillah Muhammad bin Ạmmad bin 'Abd al-Hadī al-Dimasyq̄̄ al-Ṣalih̄̄i, Tabaqāt 'Ulamā' al-Hadīs, juz I (Beirut: Mu'assasah al-Risālah, 1417 H/ 1996 M), 77.

${ }^{43}$ Al-Andalusī, Asmā', 13.

${ }^{44}$ Al-Andalusī, Asmā', 12.
1. Tingkatan yang masuk Islam pertama di Mekkah, seperti khulafä' al-'Arba'ah.

2. Sahabat-sahabat yang masuk Islam sebelum musyawarah kaum Mekkah di dār al-Nadwah.

3. Sahabat-sahabat yang hijrah ke Habasyah.

4. Sahabat-sahabat yang tergolong dalam perjanjian aqabah pertama

5. Sahabat-sahabat yang tergolong dalam perjanjian aqabah kedua, kebanyakan dari golongan ini adalah al-Anșār

6. Sahabat-sahabat pertama yang hijrah dan sampai di Qubā' bersama Rasul sebelum masuk ke Madinah

7. Sahabat-sahabat yang ikut perang Badar.

8. Sahabat-sahabat yang hijrah antara peristiwa Badar dan Hudaibiyah.

9. Sahabat-sahabat yang ikut bai'at ridwān di Hudaibiyah

10. Sahabat-sahabat yang hijrah antara perjanjian Hudaibiyah dan Fath Makkah, seperti Khālid bin Walīd dan 'Amrū bin al-'Āṣ

11. Sahabat-sahabat yang Islam di kejadian Fath Makkah.

12. Sahabat-sahabat yang masih kecil dan bayi ketika peristiwa Fath Makkah terjadi. 
Masih di buku yang sama, Asmā' alṢahāahah wa mā likulli Wāhidin Minhum min al-'Adad, Ibnu Ḥazm yang mempunyai nama lengkap Abū Muhammad 'Alī bin Aḥmad bin 'Abdullāh bin Sa'id bin Hazm al-Ẓahirah al-Andalusī, menukil dari berbagai sumber mengenai jumlah-jumlah hadis yang diriwayatkan oleh para sahabat. $^{45}$ Dengan catatan, jumlah ini adalah yang terangkum dalam Musnad A ḥmad yang merangkum 750.000 hadis. ${ }^{46}$

1. Abū Hurayrah, 3948 hadis. Dalam penuturan Ibnu Jauzī 5374 hadis.

2. ' $\bar{A}$ 'isyah, 282 hadis. Dalam penuturan Ibnu Jauzi 2210 hadis.

3. Anas bin Mālik, 2178 hadis. Dalam penuturan Ibnu Jawzī 2286 hadis.

4. Ibnu 'Abbās, 1696 hadis. Dalam penuturan Ibnu Jawzī 1660 hadis.

5. Ibnu 'Umar, 2019 hadis. Dalam penuturan Ibnu Jawzī 2620 hadis.

6. Jābir bin 'Abdullāh, 1206 hadis. Dalam penuturan Ibnu Jawzī 1540 hadis.

7. Abū Sa‘īd al-Khudrī, 958 hadis. Dalam penuturan Ibnu Jawzī 1170 hadis.

8. Ibnu Mas'ūd, 892 hadis. Dalam penuturan Ibnu Jawzi 848 hadis.
9. Ibnu Amrū bin al-Āṣ, 722 hadis. Dalam penuturan Ibnu Jawzī 700 hadis.

\section{Keadilan Sahabat}

Sebagaimana yang telah disinggung sebelumnya bahwa Ulama sepakat (ittafaqa) semua sahabat adalah adil ('udūl), kecuali pendapat-pendapat aneh dari golongan yang menyimpang (illā syużuż min mubtadi'ah). ${ }^{47}$ Hal ini penting untuk ditegaskan karena kedudukan sahabat yang adil ('adālah al-șahāabah) sangat memengaruhi, meminjam istilah Ibnu Mulaqqin, muttașil atau mursal-nya suatu hadis. ${ }^{48}$ Untuk itu, di bagian ini, perlu dijelaskan lebih terperinci lagi makna keadilan sahabat ('adālah al-ṣahāàbh).

Secara bahasa, ada dua kata yang perlu diketahui maknanya. Pertama adalah 'adālah dan yang kedua adalah al-ṣahāabah.

Jalāl al-Dīn al-Suyūṭī merumuskan pengertian 'adālah sebagai kedudukan seseorang (milkah tahammul șāhibuhā) yang melazimkan dalam dirinya takwa dan murū'ah. 'Adl itu adalah muslim, bālig, 'āqil, dan terhindar dari sebab-sebab fāsiq dan cela-cela murū'ah. 'Adl bukan orang

${ }^{45}$ Al-Andalusī, $A s m \bar{a}, 1$ 17-18.

${ }^{46} \mathrm{Al}$-Andalusī, Asmā', 16.

\footnotetext{
${ }^{47}$ Al-'Asqalānī, al-Ișābah, juz I, 162.

${ }^{48}$ Sirāj al-Dīn 'Umar bin 'Alī bin Ahmad AlAnșārī, al-Muqni' fì 'Ulūm al-Hadīis, juz 2 (Saudi: Dār Fawwaz li al-Nasyr, 1413 H/1992 M), 490.
} 
yang tidak punya dosa karena jika demikian maka tidak ada ' $a d l$. $^{49}$

Hammam 'Abd al-Rahịm Sa'īd, dalam al-Fikr al-Manhajī 'inda alMuḥaddisīn, menjelaskan dua cara mengetahui keadilan untuk menyimpulkan definisi adil itu sendiri. Tulisnya dalam satu pembahasan khusus bahwa 'adālah diketahui dengan dua cara, yaitu: ${ }^{50}$

1. Periwayat-termasuk dari golongan sahabat, mestilah diketahui ke'adālah-annya dan ketakwaannya oleh mayoritas manusia. Jika disebutkan misalnya $\mathrm{Sa}^{`}{ }^{\top} \overline{\mathrm{d}} \mathrm{b}$ bin Musayyab, Mālik bin Anas, Ḥasan alBașrī, maka nama-nama mereka telah secara otomatis terkait dengan sifat 'adālah dan warā'. Namun, bukan berarti pernyataan mereka sebagai orang yang 'adālah disepakati oleh setiap ulama. Hal itu karena ada sekelompok golongan yang menuduh Mālik bin Anas dan Muḥammad bin Isḥāq telah bertikai, meskipun dua hal ini tidak didukung dengan dalil dan hujjah yang diterima.

2. Periwayat-termasuk dari golongan sahabat, mestilah bebas dari kritik al-

${ }^{49}$ Jalāl al-Dīn Abī al-Faḍl 'Abd al-Raḥman bin Abī Bakr al-Suyūṭị, al-Bahr allaẓi Zakhara fi Syarh Alfiyah al-Asar (Madinah: Maktabah alGharba' al-Asariyah, 1420 H/ 1999 M), 312.

${ }^{50}$ Hammam 'Abd al-Raḥim Sa'īd, al-Fikr alManhajī 'inda al-Muhaddisin (Qatar: Ri'āsah alMuhakam al-Syar'iyyah wa al-Syu'ūn al-Dīniyah, $1408 \mathrm{H}), 92$.
'Árifin. Jika ada beberapa ulama atau bahkan satu ulama yang menyaksikan seorang periwayat adalah 'âdil maka, ia terhitung ādil. Tāj al-Dīn al-Subkī dalam Qāidah fì al-Jarh wa al'Ta'dìl mengatakan bahwa "Siapa saja yang ditetapkan keadilannya, siapa saja yang banyak orang memuji kesuciannya, dan jarang orang yang mengkritik celanya, maka ia lebih dekat kepada ke-'adālah-an.

Dari kedua definisi di atas, berikut adalah kesimpulan indikator yang harus dimiliki oleh orang-orang yang ādil: (1) muslim, (2) bālig, (3) 'āqil, (4) takwa, (5) murū'ah, (6) terhindar dari sebab-sebab fāsiq, (7) terhindar dari cela-cela murū'ah, (8) diakui ke- 'adālah-annya dan (9) bebas dari kritik al-'Árifin.

Adapun sahabat, sebagaimana telah diterangkan sebelumnya, adalah orang yang berjumpa dengan Nabi saw dalam keadaan beriman dan wafat dalam keadaan Islam. Pengertian berjumpa di sini adalah sahabatsahabat yang ikut majelis Rasulullah dalam waktu yang lama atau hanya sebentar saja, sahabat-sahabat yang meriwayatkan hadis atau tidak, sahabat-sahabat yang ikut berperang bersama Rasulullah atau tidak. Juga, termasuk dalam pengertian ini, sahabat yang melihat Nabi meskipun tidak 
dalam satu majelis, bahkan yang tidak melihat sekalipun karena buta. ${ }^{51}$

Dengan demikian, kesimpulan bahwa semua sahabat adalah 'udūl berarti semua sahabat mempunyai indikatorindikator berikut ini; (1) muslim, (2) bālig, (3) 'āqil, (4) takwa, (5) murū'ah,

terhindar dari sebab-sebab fāsiq,

terhindar dari cela-cela murū'ah, (8) diakui ke- 'adālah-annya dan (9) bebas dari kritik al-'Ārifin.

Ibnu Hazm menyatakannya secara jelas dalam Asmā' al-Ṣahābah wa mà likulli Wāhidin Minhum min al-'Adad: sikap mereka, yaitu para sahabat dalam sengaja berbohong mengenai riwayat-riwayat hadis yang disampaikan, ataupun menyelewengkannya (inḥirāf) dengan melakukan hal-hal yang membuat hadis tersebut tertolak. Dengan menyikapi bahwa semua sahabat adalah 'udūl maka semua yang dari mereka adalah diterima tanpa membebani (takāluf) para peneliti untuk mencari ke-adālah-annya lagi. Adapun yang terkait dengan fitnah-fitnah kepada mereka, ${ }^{52}$ maka terhitung (yuhammal)

\footnotetext{
${ }^{51}$ Al-'Asqalānī, al-Iṣāabah, juz I, 158. Lihat juga al-Mansyāwīi, Qāmūs, 72.

${ }^{52}$ Ibnu Mulaqqin dalam al-Muqni' fì 'Ulūm al-Hadīs, menjelaskan bahwa fitnah-fitnah itu senantiasa digunakan oleh orang-orang yang menolak ke- 'adālah-an sahabat. Dengan menukil catatan Ibnu Hajib dalam Muntahā al-Wușūl, ia menyebutkan dua contoh. Pertama, adalah riwayat Abū Dāwud (4394) tentang kejadian șafwān bin Umayyah yang berkata bahwa dirinya tidur di Mesjid. Kala itu di atasnya serban yang harganya 30
}

bahwa itu adalah ijtihad yang telah dibalas (al-ijtiḥ̂̄d al-ma'jūr) bagi mereka; dan itulah bentuk husn al-ẓann bagi mereka; karena mereka adalah yang membawa pertama kali nilai-nilai syariat, dan mereka pula adalah generasi terbaik yang telah disabdakan Nabi Muhammad saw. ${ }^{53}$

\section{Kesimpulan}

Tentu tidak mungkin untuk menjelaskan secara lengkap bagaimana hadis pada Masa Nabi Muhammad saw dan Sahabat dalam lembaran terbatas ini. Namun, paling tidak, ada beberapa kesimpulan yang dapat diambil dari pembahasan di atas.

Cara sahabat menerima hadis masa Nabi saw adalah (1) menghafal, (2) menulis dan (3) memraktekkannya. Sumber-sumber catatan, tulisan dan praktek mereka adalah majelis-majelis Ilmu Nabi, kejadiankejadian bersama Nabi, putusan-putusan Nabi atas pertanyaan mereka ataupun halhal yang mereka lihat dari Nabi. Sahabat juga saling bertukar informasi mengenai hadis yang mereka peroleh.

dirham. Maka, ada seseorang yang datang dan mencurinya. Kala itu, si pencuri datang kepada Rasul dan Rasul memerintahkan untuk memotong tangannya. Kedua, adalah riwayat yang dimuat șậhayn dan lainnya dari hadis mayoritas sahabat, bahwa Jābir bin Samrah berkata telah melihat Ma'iz bin Mālik datang bersama Rasulullah dan datang kepada mereka seorang laki-laki yang bersaksi empat kali bahwa ia telah berzina. Al-Anșārī, alMuqni', juz 2, 492.

$$
{ }^{53} \text { Al-Andalusī, Asmā', } 9 .
$$


Tentang perintah dan larangan menulis hadis masa Nabi saw tidak bersifat 'àm atau menyeluruh kepada seluruh sahabat Nabi. Ada sahabat-sahabat yang diizinkan dalam menuliskannya, bahkan diperintah. Larangan menulis dikarenakan khawatir akan bercampur dengan nas Alquran atau teralihkan dari perhatian kepada Alquran.

Para sahabat memelihara hadis dengan baik. Hal itu dengan memelihara dari hilangnya, dengan menghafal, menulis, dan memraktekkannya atau memeliharanya dari bercampur dengan nas Alquran atau kepalsuan yang dibuat-buat yaitu dengan hati-hati dalam menerima riwayat dari sahabat sebagaimana dicontohkan khalifah yang empat dalam tulisan ini.

Penyebaran hadis di masa para sahabat tidak terlepas dari luasnya wilayah yang dikembangkan oleh Islam pada masa itu.
Jumlah para sahabat tidak terperinci. Namun, Ulama sepakat (ittafaqa) bahwa semua sahabat adalah adil ('udūl), kecuali pendapat-pendapat aneh dari golongan yang menyimpang (illā syużüż min mubtadi'ah). Sahabat yang pertama adalah yang masyhur dengan nama Abū Bakr al-Ṣiddīq. Sedangkan yang terakhir meninggal dunia adalah Abū al-Ṭufail ‘Āmir bin Wāsisilah alLaisii yang meninggal di Mekkah $110 \mathrm{H}$.

Tentang ke-'adālah-an ada 9 indikator, yaitu (1) muslim, (2) bālig, (3) 'āqil, (4) takwa, (5) murū'ah, (6) terhindar dari sebab-sebab fāsiq, (7) terhindar dari cela-cela murū'ah, (8) diakui ke- 'adālah-annya dan (9) bebas dari kritik al-'Árifín. Namun, harus ada husn al-zann bagi mereka. Adapun pertikaian antaranya adalah ijtihad masing-masing yang telah dibalas (al-ijtiḥ̄ad al-ma'jūr).

\section{Daftar Pustaka}

Abū Zahw. Muḥammad Muhammad. Al-Hadīs wa al-Muhaddis̄ūn al-'Ināyah al-Ummah alIslāmiyah bi al-Sunnah al-Muhammadiyyah. Riyad: al-Ri'āsah al-'Āmmah li Idārah al-Buhūis al-'Ilmiyah wa al-Iftā’ wa al-Da'wah, 1404 H/ 1984 M.

al-Andalusī, Abū Muḥammad 'Alī bin Aḥmad bin 'Abdullāh bin Sa'īd bin Ḥazm al-Ẓahirah. Asmā' al-Ṣahāăbh wa Mā likulli Wāhịī̄n Minhum min al- 'Adad. Riyad: Maktabah alSa'i, t.th.

al-Anșārī. Sirāj al-Dīn 'Umar bin 'Alī bin Aḥmad. Al-Muqni' fì 'Ulūm al-Hadīs. Juz 2. Saudi: Dār Fawwaz li al-Nasyr, 1413 H/1992 M. 
Al-A‘ẓamī. Muḥammad Musțafā. Dirāsāt fì al-Hadīs al-Nabaw̄̄ wa Tārīkh Tadwìnih. Beirut: Maktab al-Islāmī, 1400 H/ 1980 M.

. Kuttāb al-Nabì Sallā Allāh 'alaihi wa Sallam. Cet. II. Beirut: al-Maktab al-Islāmī, 1398 H/ 1978 M.

- Studies In Hadīth Methodology And Literature. Indiana: American Trust Publications, 1977.

Edi. Relit Nur. Al-Sunnah (Hadis); Suatu Kajian Aliran Ingkar Sunnah dalam Jurnal Asas, Vol. 6, No. 2, Juli 2014.

Ibn al-'Asqalānī. Aḥmad bin 'Alī. Al-Iṣābah. Juz I. Beirut: Dār al-Kutub al-'Ilmiyah, 1415 H/ 1995 M.

. Tahzīb al-Tahẓīb. Juz VII. India: Majlis Da'irah al-Ma‘ārif al-Nizāamiyyah, 1325 H.

Ibnu Anas, Mālik. al-Muwațta’. Mesir: Dār al- Sya 'b, t.th.

al-Khațīb, Muḥammad 'Ajjāj. Al-Sunnah qabl al-Tadwīn. Kairo: Maktabah Wahbah, 1963.

. Ușūl al-Hadìis: 'Ulūmuh wa Mustalaḥuh. Cet. II. Beirut: Dār al-Fikr, 1391 H/1971

M.

Khon. Abdul Majid. Paham Ingkar Sunah di Indonesia (Studi Tentang Pemikirannya) dalam Jurnal Teologia, Vol. 23, No. 1, Januari 2012.

al-Mansyāwī. Muḥammad Șiddīq. Qāmūs Muștalaḥ̂̄t al-Hadīì al-Nabawī. Kairo: Dar alFāḍilah, t.th.

al-Rāḥilī, Ibrāhīm bin 'Āmir. Mauqifu Ahl al-Sunnah wa al-Jamā'ah min Ahl al-Ahwā'i wa al-Bida ‘ Juz I. Madinah: Maktabah al-Gharba’ al-Aṡariyah, $1415 \mathrm{H}$.

Sa'īd, Hammam 'Abd al-Raḥ̄m. Al-Fikr al-Manhajī 'inda al-Muhaddisìnn. Qatar: Ri'āsah alMuhakam al-Syar'iyyah wa al-Syu'ūn al-Dīniyah, 1408 H.

al-Ṣālị̣̄i, Abū 'Abdillāh Muḥammad bin Aḥmad bin 'Abd al-Hadi al-Dimasyqī. Ṭabaqāt 'Ulamā' al-Hadìs. Juz I. Beirut: Mu'assasah al-Risālah, 1417 H/ 1996 M.

al-Ṣāliḥ. Șubḥ̄i. 'Ulūm al-Hadīis wa Mușṭalāḥh. Beirut: Dār al-'Ilmi li al-Malāyīn, 1977.

al-Sibā‘̄̄. Muștafā. Al-Sunnah wa Makānatuhā fì al-Tasrī‘ al-Islāmī. Cet. II. Beirut: AlMaktab al-Islāmī, 1396 H/ 1976 M.

al-Suyūṭ̂̄, Jalāl al-Dīn Abū al-Faḍl 'Abd al-Raḥman bin Abī Bakr. Al-Baḥr allaẓi Zakhara fì Syarh Alfiyah al-Aśar. Madinah: Maktabah al-Ghuraba’ al-Aśariyah, 1420 H/ 1999 M. Wensinck, A. J. Al-Mu 'jam al-Mufahras li Alfāz al-Hadīs al-Nabawī. Jilid V. Leiden : E. J. Brill, 1936. 
al-Żahabī, Abū 'Abdillāh Syams al-Dīn. Tażkirah al-Huffāz, Juz I. Beirut: Dār al-Kutub alIlmiyah, t.th. 
HADIS PADA MASA NABI MUHAMMAD SAW DAN SAHABAT 